\title{
AWARENESS, ATTITUDE RESPONSE OF PARENTS TOWARD EMERGENCY MANAGEMENT OF AVULSED PERMANENT TOOTH OF THEIR CHILDREN IN EGYPT
}

\author{
Naglaa Ibrahim Ezz El-Din*
}

\begin{abstract}
Objective: The purpose of this study is the evaluation of awareness level and attitude response for a sample representing Egyptian parents towards emergency management of permanent tooth avulsion for children via questionnaire methods.

Materials and methods: A 400 parents who had a children aged between 6 to 12 years attended at the Pediatric Dentistry clinic, Faculty of Dentistry, Modern Sciences and Arts University, Cairo, Egypt. The questionnaires were distributed among this sample to evaluate the knowledge level and attitude response among those parents toward emergency management of avulsed permanent tooth.

Results: The result in this study did reveal that $17.5 \%$ of the parents had previous information about the emergency management of the avulsed permanent tooth, and $42.8 \%$ believed in the possibility of replantation of the avulsed permanent tooth, $19.2 \%$ of them could replant the tooth by themselves. $38 \%$ of parents reported the necessity of immediate replantation, $37.4 \%$ did select a saline as suitable cleaning and $45 \%$ reported saline as the suitable transport media.
\end{abstract}

Conclusion: Egyptian parents do lack the most knowledge needed for proper management of avulsed permanent tooth, that is common in all levels regardless the difference in gender, education level and geographic background.

Keywords: traumatic injury, knowledge, tooth avulsion, lost tooth, emergency treatment.

\section{INTRODUCTION}

Traumatic dental injuries are considered a serious public health challenges that have been neglected by majority of population as well as oral health professionals whom supposed to play the major role in its management ${ }^{(1)}$. Dental avulsion is defined as complete displacement of the tooth outside of the socket; it may be with or without alveolar bone fracture $^{(2)}$.

Dental avulsion commonly occurs in permanent dentition of children aged between 8 to 12 years as a result of fall and traffic accidents, contact sports

* Lecturer of Pediatric Dentistry Department, Faculty of Dentistry, Modern Sciences and Arts University, Egypt. 
or play, as loosely structured periodontal ligaments, short, incompletely developed root and low bone density lead to increased incidence of tooth avulsion in young age, while the highly susceptible tooth for avulsion is a maxillary central incisor due to its position in the dental arch followed by the lateral incisors and canines ${ }^{(3,4)}$. The occurrence of tooth avulsion ranges from 0.5 to $16 \%$ of all traumatic dental injuries of permanent dentation ${ }^{(5)}$.

Maintenance of permanent anterior teeth is not only essential for esthetics reasons but also for speech, mastication, arch discrepancy and psychological status of children ${ }^{(6,7)}$. Replacement of avulsed permanent tooth by using implant or bridge is not recommended in young age because of the possibility of interfering with the arch growth, which resuls in temporary replacement by removable partial denture in this sensitive period of child life. Moreover the replacement of permanent anterior teeth causes an economic burden on the family, so immediate replantation of avulsed permanent tooth is considered an ideal management which improving the image and self-esteem of the child ${ }^{(8,9)}$.

The most important factor affecting prognosis of replanted avulsed permanent tooth is minimizing the extra-alveolar duration of the tooth as it affects the viability of periodontal ligaments attached to the root; selection of suitable storage media during transportation of the avulsed tooth is important to prevent the dehydration of periodontal ligament ${ }^{(10)}$. Studies shown that the suitable storage media should have a proper osmolality and $\mathrm{PH}$ to maintain the vitality of periodontal ligaments, milk is considered an ideal storage media as it is reachable and fulfill these requirements ${ }^{(11)}$.

Since the majority of traumatic dental injuries occurs at home, the knowledge and the awareness of the parents about the proper management of dental avulsion is essential for proper prognosis of the treatment. Several studies in different countries revealed that the knowledge of the population about the management of avulsed permanent tooth is very low ${ }^{(11,12,13,14)}$.

The aim of this study is the evaluation of awareness level and attitude response for a sample representing Egyptian parents towards emergency management of permanent tooth avulsion for children via questionnaire methods.

\section{MATERIALS AND METHODS}

The present study was a questionnaire based on composed of 400 parents who had a children aged between 6 to 12 years admitted at Pediatric Dentistry clinic, Faculty of Dentistry, Modern Sciences and Arts University, Cairo, Egypt. The parents asked to participate in the study during the period of February to July 2018, following Declaration of HelsinkiEthical Principles for Medical Research Involving Human Subject. The nature and the objective of the study were explained briefly to the parents. The questionnaires were distributed only to the parents who accepted to participate in this study.

The questionnaire was written in English then translated to simple Arabic language, modified from Raphael and Gregory questionnaire (15). It composed of two parts, the first part was a demographic data (gender, educational level and geographical background) and the second part was contained of a 10 questions designed to measure the awareness and attitude of parents toward emergency management of avulsed permanent tooth, the questions were closed ended provided by the multiple answers, the parents were asked to mark the appropriate answer according to their knowledge, each answer list contained correct and 
incorrect answers, any clarifications or comments regarding the questions were resolved by the author. Collection of the questionnaire were done immediately after the parents had completed it, and then followed by distribution of leaflets containing education of proper measures of management of avulsed permanent tooth to the participated parents.

\section{Statistical analysis}

Data were statistically described in terms of frequencies (number of cases) and percentages and compared using Chi-square $\left(\mathrm{c}^{2}\right)$ test. Exact test was used instead when the expected frequency is less than 5. $p$ values less than 0.05 was considered statistically significant. All statistical calculations were done using computer program IBM SPSS (Statistical Package for the Social Science; IBM Corp, Armonk, NY, USA) release 22 for Microsoft Windows.

\section{RESULTS}

A total 400 parent who had a children aged between 6 to 12 years attended at the Pediatric Dentistry clinic, Faculty of Dentistry, Modern Sciences and Arts University, Cairo, Egypt were included in this study. Demographic data of this study have been presented in (table 1).

The result of this study revealed that $17.5 \%$ of the parents had previous information about the emergency management of the avulsed permanent tooth, $43.5 \%$ gained the information from others and $30.4 \%$ from hospitals (table 2).

$95.5 \%$ of parents reported the necessity of saving permanent tooth, and $42.8 \%$ believed in the possibility of replantation of the avulsed permanent tooth, $19.2 \%$ of them could replant the tooth by themselves (table 2).
The questions related to the replantation technique didn't answer by who didn't believe in possibility of replantation. $38 \%$ of parents reported the necessity of immediate replantation while $30.4 \%$ preferred to replant it after the bleeding has stopped and $19 \%$ will delayed the replantation for several days. $37.4 \%$ of parents were selected a saline as suitable cleaning media, $25 \%$ selected the brush and $16.4 \%$ selected the water. $45 \%$ of the parents have reported that the suitable transport media is the saline and the milk was reported by $17 \%$ (table 2).

$76.3 \%$ of parents will seeking a dentist as a first place to contact followed by $22 \%$ will seeking the hospital. Among all parents $10.5 \%$ only had a previous experience with avulsed permanent tooth. (table 2)

There was no statistically significant difference between any of this demographic data except the educational level in relation to the possibility of replantation, as the illiterate parents have showed law awareness toward the avulsed tooth replantation (table 2, 3.4).

TABLE (1): Demographic data of the parents

\begin{tabular}{|l|c|c|}
\hline Variable & $\mathbf{n}$ & $\boldsymbol{\%}$ \\
\hline Gender: & 110 & $27.5 \%$ \\
- Males & 290 & $72.5 \%$ \\
\hline - Females & & \\
\hline Educational levels: & 80 & $20.0 \%$ \\
- Illiterate & 71 & $17.8 \%$ \\
- Elementary & 141 & $35.3 \%$ \\
- Higher secondary school & 108 & $27.0 \%$ \\
- University or higher & & \\
\hline Geographical background: & 262 & $65.5 \%$ \\
- Urban & 138 & $34.5 \%$ \\
\hline
\end{tabular}


TABLE (2): Response of parents of different gender toward emergency management of avulsed permanent tooth.

\begin{tabular}{|c|c|c|c|c|c|c|c|}
\hline \multirow{2}{*}{ Question } & \multirow{2}{*}{ Answers } & \multicolumn{2}{|c|}{ Males } & \multicolumn{2}{|c|}{ Females } & \multirow{2}{*}{$\begin{array}{r}\text { Total } \\
\%\end{array}$} & \multirow{2}{*}{$p$ value } \\
\hline & & $\mathbf{n}$ & $\%$ & $\mathbf{n}$ & $\%$ & & \\
\hline \multirow[t]{2}{*}{ Previous information } & Yes & 21 & $19.1 \%$ & 49 & $16.9 \%$ & $17.5 \%$ & \multirow{2}{*}{0.606} \\
\hline & No & 89 & $80.9 \%$ & 241 & $83.1 \%$ & $82.5 \%$ & \\
\hline \multirow[t]{5}{*}{ Source of information } & Media & 2 & $10.0 \%$ & 6 & $12.2 \%$ & $11.6 \%$ & \multirow{5}{*}{$0.009 *$} \\
\hline & Book & 0 & $0.0 \%$ & 3 & $6.1 \%$ & $4.4 \%$ & \\
\hline & Internet & 6 & $30.0 \%$ & 1 & $2.0 \%$ & $10.1 \%$ & \\
\hline & Health services & 6 & $30.0 \%$ & 15 & $30.6 \%$ & $30.4 \%$ & \\
\hline & Others & 6 & $30.0 \%$ & 24 & $49.0 \%$ & $43.5 \%$ & \\
\hline \multirow{2}{*}{$\begin{array}{l}\text { Necessity of saving of } \\
\text { permanent tooth }\end{array}$} & Yes & 105 & $95.5 \%$ & 277 & $95.5 \%$ & $95.5 \%$ & \multirow{2}{*}{0.978} \\
\hline & No & 5 & $4.5 \%$ & 13 & $4.5 \%$ & $4.5 \%$ & \\
\hline \multirow[t]{2}{*}{ Possibility of reimplantation } & Yes & 47 & $42.7 \%$ & 124 & $42.8 \%$ & $42.8 \%$ & \multirow{2}{*}{0.995} \\
\hline & No & 63 & $57.3 \%$ & 166 & $57.2 \%$ & $57.2 \%$ & \\
\hline \multirow[t]{2}{*}{ Self reimplantation } & Yes & 13 & $27.7 \%$ & 20 & $16.0 \%$ & $19.2 \%$ & \multirow{2}{*}{0.084} \\
\hline & No & 34 & $72.3 \%$ & 105 & $84.0 \%$ & $80.8 \%$ & \\
\hline \multirow[t]{5}{*}{ Ideal timing of reimplantation } & Immediately & 20 & $42.6 \%$ & 45 & $36.3 \%$ & $38 \%$ & \multirow{5}{*}{0.183} \\
\hline & After bleeding stopped & 14 & $29.8 \%$ & 38 & $30.6 \%$ & $30.4 \%$ & \\
\hline & Within one hour & 2 & $4.3 \%$ & 6 & $4.8 \%$ & $4.7 \%$ & \\
\hline & At the same day & 6 & $12.8 \%$ & 6 & $4.8 \%$ & $7 \%$ & \\
\hline & After several days & 5 & $10.6 \%$ & 29 & $23.4 \%$ & $19.9 \%$ & \\
\hline \multirow[t]{7}{*}{ Suitable cleaning media } & Water & 11 & $23.4 \%$ & 17 & $13.7 \%$ & $16.4 \%$ & \multirow{7}{*}{0.480} \\
\hline & Saline & 18 & $38.3 \%$ & 46 & $37.1 \%$ & $37.4 \%$ & \\
\hline & Milk & 2 & $4.3 \%$ & 7 & $5.6 \%$ & $5.3 \%$ & \\
\hline & Disinfectant solution & 4 & $8.5 \%$ & 12 & $9.7 \%$ & $9.4 \%$ & \\
\hline & Nothing & 3 & $6.4 \%$ & 3 & $2.4 \%$ & $3.5 \%$ & \\
\hline & Brush & 8 & $17.0 \%$ & 35 & $28.2 \%$ & $25.1 \%$ & \\
\hline & Others & 1 & $2.1 \%$ & 4 & $3.2 \%$ & $2.9 \%$ & \\
\hline \multirow[t]{7}{*}{ Suitable transport media } & Water & 5 & $10.6 \%$ & 9 & $7.3 \%$ & $8.2 \%$ & \multirow{7}{*}{0.393} \\
\hline & Saline & 18 & $38.3 \%$ & 59 & $47.6 \%$ & $45 \%$ & \\
\hline & Milk & 12 & $25.5 \%$ & 17 & $13.7 \%$ & $17 \%$ & \\
\hline & Handkerchief & 5 & $10.6 \%$ & 15 & $12.1 \%$ & $11.7 \%$ & \\
\hline & Disinfectant solution & 3 & $6.4 \%$ & 16 & $12.9 \%$ & $11.1 \%$ & \\
\hline & Nothing & 1 & $2.1 \%$ & 4 & $3.2 \%$ & $2.9 \%$ & \\
\hline & Others & 3 & $6.4 \%$ & 4 & $3.2 \%$ & $4.1 \%$ & \\
\hline \multirow[t]{3}{*}{ First medical service of contact } & Dentist & 86 & $78.2 \%$ & 219 & $75.5 \%$ & $76.3 \%$ & \multirow{3}{*}{0.681} \\
\hline & Hospital & 23 & $20.9 \%$ & 65 & $22.4 \%$ & $22 \%$ & \\
\hline & General practitioner & 1 & $0.9 \%$ & 6 & $2.1 \%$ & $1.7 \%$ & \\
\hline \multirow{2}{*}{$\begin{array}{l}\text { Previous experience with } \\
\text { avulsion injury }\end{array}$} & Yes & 12 & $10.9 \%$ & 30 & $10.3 \%$ & $10.5 \%$ & \multirow{2}{*}{0.869} \\
\hline & No & 98 & $89.1 \%$ & 260 & $89.7 \%$ & $89.5 \%$ & \\
\hline
\end{tabular}


TABLE (3): Response of parents of different educational level toward emergency management of avulsed permanent tooth.

\begin{tabular}{|c|c|c|c|c|c|c|c|c|c|c|}
\hline \multirow[t]{2}{*}{ Question } & \multirow[t]{2}{*}{ Answers } & \multicolumn{2}{|c|}{ Illiterate } & \multicolumn{2}{|c|}{ Preliminary } & \multicolumn{2}{|c|}{$\begin{array}{c}\text { Higher } \\
\text { secondary } \\
\text { school }\end{array}$} & \multicolumn{2}{|c|}{$\begin{array}{l}\text { University or } \\
\text { higher }\end{array}$} & \multirow[t]{2}{*}{ p value } \\
\hline & & $\mathbf{n}$ & $\%$ & $\mathbf{n}$ & $\%$ & $\mathbf{n}$ & $\%$ & $\mathbf{n}$ & $\%$ & \\
\hline \multirow[t]{2}{*}{ Previous information } & Yes & 10 & $12.5 \%$ & 9 & $12.7 \%$ & 25 & $17.7 \%$ & 26 & $24.1 \%$ & \multirow{2}{*}{0.123} \\
\hline & No & 70 & $87.5 \%$ & 62 & $87.3 \%$ & 116 & $82.3 \%$ & 82 & $75.9 \%$ & \\
\hline \multirow[t]{5}{*}{ Source of information } & Media & 2 & $20.0 \%$ & 2 & $22.2 \%$ & 2 & $8.0 \%$ & 2 & $8.0 \%$ & \multirow{5}{*}{0.303} \\
\hline & Book & 0 & $0.0 \%$ & 0 & $0.0 \%$ & 1 & $4.0 \%$ & 2 & $8.0 \%$ & \\
\hline & Internet & 0 & $0.0 \%$ & 0 & $0.0 \%$ & 2 & $8.0 \%$ & 5 & $20.0 \%$ & \\
\hline & Health services & 1 & $10.0 \%$ & 4 & $44.4 \%$ & 7 & $28.0 \%$ & 9 & $36.0 \%$ & \\
\hline & Others & 7 & $70.0 \%$ & 3 & $33.3 \%$ & 13 & $52.0 \%$ & 7 & $28.0 \%$ & \\
\hline \multirow{2}{*}{$\begin{array}{l}\text { Necessity of saving of } \\
\text { permanent tooth }\end{array}$} & Yes & 74 & $92.5 \%$ & 71 & $100.0 \%$ & 133 & $94.3 \%$ & 104 & $96.3 \%$ & \multirow{2}{*}{0.131} \\
\hline & No & 6 & $7.5 \%$ & 0 & $0.0 \%$ & 8 & $5.7 \%$ & 4 & $3.7 \%$ & \\
\hline \multirow{2}{*}{$\begin{array}{l}\text { Possibility of } \\
\text { reimplantation }\end{array}$} & Yes & 22 & $27.5 \%$ & 31 & $43.7 \%$ & 65 & $46.1 \%$ & 53 & $49.1 \%$ & \multirow{2}{*}{$0.018^{*}$} \\
\hline & No & 58 & $72.5 \%$ & 40 & $56.3 \%$ & 76 & $53.9 \%$ & 55 & $50.9 \%$ & \\
\hline \multirow[t]{2}{*}{ Self reimplantation } & Yes & 8 & $36.4 \%$ & 7 & $22.6 \%$ & 9 & $13.6 \%$ & 9 & $17.0 \%$ & \multirow{2}{*}{0.117} \\
\hline & No & 14 & $63.6 \%$ & 24 & $77.4 \%$ & 57 & $86.4 \%$ & 44 & $83.0 \%$ & \\
\hline \multirow{5}{*}{$\begin{array}{l}\text { Ideal timing of } \\
\text { reimplantation }\end{array}$} & Immediately & 11 & $50.0 \%$ & 9 & $29.0 \%$ & 25 & $38.5 \%$ & 20 & $37.7 \%$ & \multirow{5}{*}{0.796} \\
\hline & After bleeding stopped & 7 & $31.8 \%$ & 9 & $29.0 \%$ & 17 & $26.2 \%$ & 19 & $35.8 \%$ & \\
\hline & Within one hour & 0 & $0.0 \%$ & 1 & $3.2 \%$ & 4 & $6.2 \%$ & 3 & $5.7 \%$ & \\
\hline & At the same day & 1 & $4.5 \%$ & 4 & $12.9 \%$ & 4 & $6.2 \%$ & 3 & $5.7 \%$ & \\
\hline & After several days & 3 & $13.6 \%$ & 8 & $25.8 \%$ & 15 & $23.1 \%$ & 8 & $15.1 \%$ & \\
\hline \multirow[t]{7}{*}{ Suitable cleaning media } & Water & 5 & $22.7 \%$ & 0 & $0.0 \%$ & 11 & $16.9 \%$ & 12 & $22.6 \%$ & \multirow{7}{*}{0.147} \\
\hline & Saline & 7 & $31.8 \%$ & 15 & $48.4 \%$ & 21 & $32.3 \%$ & 21 & $39.6 \%$ & \\
\hline & Milk & 1 & $4.5 \%$ & 0 & $0.0 \%$ & 6 & $9.2 \%$ & 2 & $3.8 \%$ & \\
\hline & Disinfectant solution & 1 & $4.5 \%$ & 4 & $12.9 \%$ & 7 & $10.8 \%$ & 4 & $7.5 \%$ & \\
\hline & Nothing & 2 & $9.1 \%$ & 1 & $3.2 \%$ & 1 & $1.5 \%$ & 2 & $3.8 \%$ & \\
\hline & Brush & 4 & $18.2 \%$ & 11 & $35.5 \%$ & 16 & $24.6 \%$ & 12 & $22.6 \%$ & \\
\hline & Others & 2 & $9.1 \%$ & 0 & $0.0 \%$ & 3 & $4.6 \%$ & 0 & $0.0 \%$ & \\
\hline \multirow[t]{7}{*}{ Suitable transport media } & Water & 1 & $4.5 \%$ & 2 & $6.5 \%$ & 5 & $7.7 \%$ & 6 & $11.3 \%$ & \multirow{7}{*}{0.227} \\
\hline & Saline & 5 & $22.7 \%$ & 16 & $51.6 \%$ & 31 & $47.7 \%$ & 25 & $47.2 \%$ & \\
\hline & Milk & 4 & $18.2 \%$ & 4 & $12.9 \%$ & 12 & $18.5 \%$ & 9 & $17.0 \%$ & \\
\hline & Handkerchief & 7 & $31.8 \%$ & 2 & $6.5 \%$ & 6 & $9.2 \%$ & 5 & $9.4 \%$ & \\
\hline & Disinfectant solution & 2 & $9.1 \%$ & 5 & $16.1 \%$ & 9 & $13.8 \%$ & 3 & $5.7 \%$ & \\
\hline & Nothing & 2 & $9.1 \%$ & 1 & $3.2 \%$ & 1 & $1.5 \%$ & 1 & $1.9 \%$ & \\
\hline & Others & 1 & $4.5 \%$ & 1 & $3.2 \%$ & 1 & $1.5 \%$ & 4 & $7.5 \%$ & \\
\hline \multirow{3}{*}{$\begin{array}{l}\text { First medical service of } \\
\text { contact }\end{array}$} & Dentist & 62 & $77.5 \%$ & 52 & $73.2 \%$ & 107 & $75.9 \%$ & 84 & $77.8 \%$ & \\
\hline & Hospital & 15 & $18.8 \%$ & 18 & $25.4 \%$ & 31 & $22.0 \%$ & 24 & $22.2 \%$ & 0.574 \\
\hline & General practitioner & 3 & $3.8 \%$ & 1 & $1.4 \%$ & 3 & $2.1 \%$ & 0 & $0.0 \%$ & \\
\hline Previous experience with & Yes & 10 & $12.5 \%$ & 7 & $9.9 \%$ & 11 & $7.8 \%$ & 14 & $13.0 \%$ & 0540 \\
\hline avulsion injury & No & 70 & $87.5 \%$ & 64 & $90.1 \%$ & 130 & $92.2 \%$ & 94 & $87.0 \%$ & \\
\hline
\end{tabular}

*: Significant at $P \leq 0.05$ 
TABLE (4): Response of parents of different geographic background toward emergency management of avulsed permanent tooth.

\begin{tabular}{|c|c|c|c|c|c|c|}
\hline \multirow{2}{*}{ Question } & \multirow{2}{*}{ Answers } & \multicolumn{2}{|c|}{ Urban } & \multicolumn{2}{|c|}{ Rural } & \multirow{2}{*}{ p value } \\
\hline & & $\mathbf{n}$ & $\%$ & $\mathbf{n}$ & $\%$ & \\
\hline \multirow[t]{2}{*}{ Previous information } & Yes & 43 & $16.4 \%$ & 27 & $19.6 \%$ & \multirow{2}{*}{0.430} \\
\hline & No & 219 & $83.6 \%$ & 111 & $80.4 \%$ & \\
\hline \multirow[t]{5}{*}{ Source of information } & Media & 4 & $9.5 \%$ & 4 & $14.8 \%$ & \multirow{5}{*}{0.705} \\
\hline & Book & 2 & $4.8 \%$ & 1 & $3.7 \%$ & \\
\hline & Internet & 4 & $9.5 \%$ & 3 & $11.1 \%$ & \\
\hline & Health services & 11 & $26.2 \%$ & 10 & $37.0 \%$ & \\
\hline & Others & 21 & $50.0 \%$ & 9 & $33.3 \%$ & \\
\hline \multirow{2}{*}{$\begin{array}{l}\text { Necessity of saving of } \\
\text { permanent tooth }\end{array}$} & Yes & 250 & $95.4 \%$ & 132 & $95.7 \%$ & \multirow{2}{*}{0.915} \\
\hline & No & 12 & $4.6 \%$ & 6 & $4.3 \%$ & \\
\hline \multirow[t]{2}{*}{ possibility of reimplantation } & Yes & 116 & $44.3 \%$ & 55 & $39.9 \%$ & \multirow{2}{*}{0.396} \\
\hline & No & 146 & $55.7 \%$ & 83 & $60.1 \%$ & \\
\hline \multirow[t]{2}{*}{ Self reimplantation } & Yes & 24 & $20.5 \%$ & 9 & $16.4 \%$ & \multirow{2}{*}{0.519} \\
\hline & No & 93 & $79.5 \%$ & 46 & $83.6 \%$ & \\
\hline \multirow[t]{5}{*}{ Ideal timing of reimplantation } & Immediately & 44 & $37.9 \%$ & 21 & $38.2 \%$ & \multirow{5}{*}{0.727} \\
\hline & After bleeding stopped & 36 & $31.0 \%$ & 16 & $29.1 \%$ & \\
\hline & Within one hour & 7 & $6.0 \%$ & 1 & $1.8 \%$ & \\
\hline & At the same day & 8 & $6.9 \%$ & 4 & $7.3 \%$ & \\
\hline & After several days & 21 & $18.1 \%$ & 13 & $23.6 \%$ & \\
\hline \multirow[t]{7}{*}{ Suitable cleaning media } & Water & 19 & $16.4 \%$ & 9 & $16.4 \%$ & \multirow{7}{*}{0.949} \\
\hline & Saline & 46 & $39.7 \%$ & 18 & $32.7 \%$ & \\
\hline & Milk & 6 & $5.2 \%$ & 3 & $5.5 \%$ & \\
\hline & Disinfectant solution & 11 & $9.5 \%$ & 5 & $9.1 \%$ & \\
\hline & Nothing & 3 & $2.6 \%$ & 3 & $5.5 \%$ & \\
\hline & Brush & 28 & $24.1 \%$ & 15 & $27.3 \%$ & \\
\hline & Others & 3 & $2.6 \%$ & 2 & $3.6 \%$ & \\
\hline \multirow[t]{7}{*}{ Suitable transport media } & Water & 11 & $9.5 \%$ & 3 & $5.5 \%$ & \multirow{7}{*}{0.150} \\
\hline & Saline & 52 & $44.8 \%$ & 25 & $45.5 \%$ & \\
\hline & Milk & 19 & $16.4 \%$ & 10 & $18.2 \%$ & \\
\hline & Handkerchief & 13 & $11.2 \%$ & 7 & $12.7 \%$ & \\
\hline & Disinfectant solution & 13 & $11.2 \%$ & 6 & $10.9 \%$ & \\
\hline & Nothing & 1 & $0.9 \%$ & 4 & $7.3 \%$ & \\
\hline & Others & 7 & $6.0 \%$ & 0 & $0.0 \%$ & \\
\hline \multirow[t]{3}{*}{ First medical service of contact } & Dentist & 198 & $75.6 \%$ & 107 & $77.5 \%$ & \multirow{3}{*}{0.763} \\
\hline & Hospital & 60 & $22.9 \%$ & 28 & $20.3 \%$ & \\
\hline & General practitioner & 4 & $1.5 \%$ & 3 & $2.2 \%$ & \\
\hline \multirow{2}{*}{$\begin{array}{l}\text { Previous experience with } \\
\text { avulsion injury }\end{array}$} & Yes & 26 & $9.9 \%$ & 16 & $11.6 \%$ & \multirow{2}{*}{0.604} \\
\hline & No & 236 & $90.1 \%$ & 122 & $88.4 \%$ & \\
\hline
\end{tabular}




\section{DISCUSSION}

The importance of permanent teeth makes the proper knowledge and awareness of the parents toward management of avulsed permanent tooth is essential for saving it ${ }^{(11)}$.

The present study included 400 parents who had a children aged between 6 to 12 years attended at the Pediatric Dentistry clinic, Faculty of Dentistry, Modern Sciences and Arts University, Cairo, Egypt. A simple questionnaire was used as a good method for screening the level of parent knowledge and attitude in this study, the questions were covering all point needs to be evaluated. Section I included gender, educational level and geographic background, to study the effect of this demographic data on the parent's knowledge about management of avulsed permanent tooth in section II. The result in this study revealed that only $17.5 \%$ of the parents had a previous information about the emergency management of avulsed permanent tooth, this result was agreed with Abdellatif and Hegazy, Gurunathan et al, and Jain et al ${ }^{(11,16,17)}$. The main sources of this information were the other people, as family, relatives or friends and from the hospital. That's mean that it is very important to spread the awareness about the emergency managements of avulsed permanent tooth by mounting a posters and leaflet, organizing an educational programs especially in hospitals and health service places and in addition to media campaigns.

$42.8 \%$ of the parents in this study believe in the possibility of replantation of permanent tooth after its avulsion, in spite of $95.5 \%$ of the parent believe in the necessity of saving permanent tooth which indicate that the parents having a positive attitude toward preservation of permanent tooth in spite of low knowledge about the method of saving it, this results were agreed with Jindal et al and Gurunathan et al ${ }^{(13,16)}$. In relation to the possibility of replantation of avulsed permanent tooth there was a significant relation between the education and this result as the illiterate shown low awareness about the possibility replantation of the avulsed permanent tooth and this was agreed by Jain et al $^{(17)}$.

Among the parents who were believed in replantation of avulsed permanent tooth there were only $19.2 \%$ of them had an interest in replantation of the tooth by themselves this results agreed with Al-Jame et al, Santos et al and Mohamed et $\boldsymbol{a l}^{(18,19,20)}$, the reason for this result could be due to lack of knowledge, excessive bleeding, hurting the child or they may didn't know how to replant it.

Most of parents have believed in the necessity of immediate replantation of the avulsed permanent tooth or after the bleeding has stopped this results agreed with Jain et al ${ }^{(17)}$. Andreasen and HjortingHansen in their study concluded that the prognosis of replanted permanent tooth will be good if the tooth has been replanted before 20 minute, Lin et al in their study found that the appropriate time of reimplantation of an avulsed permanent tooth is within 30 minutes which shown $90 \%$ success ${ }^{(21,22)}$.

In this study $37.4 \%$ of parents were selected saline as suitable cleaning media followed by $25 \%$ preferred scrubbing the tooth with brush while only $16 \%$ preferred water as a cleaning media this results were agreed with Abdellatif and Hegazy and Mohamed et $\boldsymbol{a l}^{(11,20)}$ and didn't match the guidelines of the American academy of pediatric dentistry for the management of avulsed tooth as it is recommend the running water as preferable cleaning method ${ }^{(23)}$.

Selection of proper transport media for storage the avulsed permanent tooth is very important to keep the viability of the periodontal ligament until the time of replantation, the ideal storage median should preserve the cells of periodontal ligament and accessible in the place of trauma, in this study a $45 \%$ of the parents were select a saline as suitable transport media and only $17 \%$ selected milk, several studies have demonstrated a poor knowledge about transport media ${ }^{(11,19,24)}$. Milk is the most suitable 
and reachable storage media, and the viability of periodontal ligament cells in milk was inferior to Hank's Balanced Salt Solution (HBSS) ${ }^{(23,25)}$.

$76.3 \%$ of the parents have preferred to seek dentist for consultation instead of hospitals or general practitioners, even in rural area, this result was agreed with Kaul et al and Gurunathan et $\boldsymbol{a l}^{(5,16)}$ and disagreed with Qazi and Nasir and Shashikiran et al ${ }^{(9,24)}$ who were founds that rural areas seeking hospitals or general practitioners rather than dentist. $10.5 \%$ of the parents had experienced a previous traumatic dental injury causing avulsion of permanent tooth.

The results in this study showed low level of knowledge regarding the emergency management of avulsed permanent tooth, this results in accordance with other studies conducted in Egypt and different countries ${ }^{(11,12,17,18)}$. Gender, educational level and geographic background didn't show significant difference in the majority of the answers; moreover, well-educated parents have little information about the management of avulsed permanent tooth.

In spite of there were two studies have been made previously in Egypt ${ }^{(11,20)}$ and they concluded a lack of knowledge toward the emergency management of avulsed permanent tooth no attempt has been made by the dental organizations and the government in Egypt to educate the population about this serious emergency situation.

\section{CONCLUSION}

Egyptian parents do lack the most knowledge needed for proper management of avulsed permanent tooth, that is common in all levels regardless the difference in gender, education level and geographic background.

Therefore, it is a must to establish an educational programs for parents, teachers, nurses, coaches and even physicians, mounting posters and leaflets in health services and public places in addition to media campaigns to spread the awareness about emergency managements of avulsed permanent tooth, followed by several studies in different regions in Egypt to assess the awareness and the attitude of parents toward emergency management of avulsed permanent tooth, also several studies needed to assess the awareness and attitude of the teachers, coaches and general practitioner.

\section{REFERENCES}

1. Andreasen JO, Andreasen FM, Andersson L. Textbook andcolour atlas of traumatic injuries to the teeth. 4th edn. Oxford,Blackwell Munksgaard; 2007. P. 383-427.

2. Ankola A V, Hebbal M, Sharma R, Nayak SS. Traumatic dental injuries in primary school children of South India-a report from district-wide oral health survey. Dent Traumatol. 2013 Apr;29(2):134-8.

3. Glendor U. Aetiology and risk factors related to traumatic dental injuries--a review of the literature. Dent Traumatol. 2009 Feb;25(1):19-31.

4. Olatosi OO, Iwuala SO, Isiekwe GI, Oredugba FA, Adenaike AS, Oluwo AO. Knowledge and attitude of some nigerian school teachers on the emergency management of avulsed permanent incisor. J West African Coll Surg. 2013;3(4):30-52.

5. Kaul R, Jain P, Angrish P, Saha S, Patra TK, Saha N, et al. Knowledge, awareness and attitude towards emergency management of dental trauma among the parents of Kolkata-an institutional study. J Clin Diagnostic Res. 2016;10(7):95-101.

6. Adekoya-Sofowora CA, Adesina OA, Nasir WO, Oginni AO, Ugboko VI. Prevalence and causes of fractured permanent incisors in 12-year-old suburban Nigerian schoolchildren. Dent Traumatol. 2009 Jun;25(3):314-7.

7. Pujita C, Nuvvula S, Shilpa G, Nirmala S, Yamini V. Informative promotional outcome on school teachers' knowledge about emergency management of dental trauma. J Conserv Dent. 2013 Jan;16(1):21-7.

8. Andersson L, Malmgren B. The problem of dentoalveolar ankylosis and subsequent replacement resorption in the growing patient. Aust Endod J. 1999 Aug;25(2):57-61.

9. Qazi SR, Nasir KS. First-aid knowledge about tooth avulsion among dentists, doctors and lay people. Dent Traumatol. 2009 Jun;25(3):295-9. 
10. Gupta N, Singh K, Ahuja R, Saxena T. Knowledge of mothers with different education levels about the emergency management of avulsed teeth. Oral Health Dent Manag. 2014 Sep;13(3):792-7.

11. Abdellatif AM, Hegazy SA. Knowledge of emergency management of avulsed teeth among a sample of Egyptian parents. J Adv Res. 2011;2(2):157-62.

12. Ozer S, Yilmaz EI, Bayrak S, Tunc E Sen. Parental knowledge and attitudes regarding the emergency treatment of avulsed permanent teeth. Eur J Dent. 2012;6(4):370-5.

13. Jindal A, Bhargava S, Bakshi L, Verma R, Beniwal D, Namdev R. Awareness of emergency management of dental trauma. Contemp Clin Dent. 2014;5(4):507.

14. Nikam AP, Kathariya MD, Chopra K, Gupta A, Kathariya R. Knowledge and Attitude of Parents/Caretakers toward Management of Avulsed Tooth in Maharashtrian Population: A Questionnaire Method. J Int oral Heal JIOH. 2014;6(5):1-4.

15. Raphael SL, Gregory PJ. Parental awareness of the emergency management of avulsed teeth in children. Aust Dent J. 1990 Apr;35(2):130-3.

16. Gurunathan D, Somasundaram S, Loo T. Knowledge and attitude of parents with regard to avulsed permanent tooth of their children and their emergency managementChennai. J Indian Soc Pedod Prev Dent. 2014;32(2):97.

17. Jain A, Kulkarni P, Kumar S, Jain M. Knowledge and attitude of parents towards avulsed permanent tooth of their children and its emergency management in Bhopal city. J Clin Diagnostic Res. 2017;11(5):ZC40-ZC44.

18. Al-Jame Q, Andersson L, Al-Asfour A. Kuwaiti parents' knowledge of first-aid measures of avulsion and replantation of teeth. Med Princ Pract. 2007;16(4):274-9.
19. Santos MESMI, Habecost APZ, Gomes FV, Weber JBB, De Oliveira MG. Parent and caretaker knowledge about avulsion of permanent teeth. Dent Traumatol. 2009;25(2):203-8.

20. Mohamed B, El-Motayam KM, El-Shahawy OI. Knowledge and Attitude of Egyptian Parents' about Dental Injuries and Its Emergency Management in Their Children. Master degree thesis, Faculty of Oral and Dental Medicine, Cairo University. 2012.

21. Andreasen JO, Hjorting-Hansen E. Replantation of teeth. I. Radiographic and clinical study of 110 human teeth replanted after accidental loss. Acta Odontol Scand. 1966 Nov;24(3):263-86.

22. Lin S, Emodi O, Abu El-Naaj I. Splinting of an injured tooth as part of emergency treatment. Dent Traumatol. 2008 Jun;24(3):370-2.

23. Group O. Guidelines for the Management of Traumatic Dental Injuries : 2. Avulsion of Permanent Teeth. 2013; (6):412-9.

24. Shashikiran ND, Reddy VVS, Nagaveni NB. Knowledge and attitude of 2,000 parents (urban and rural - 1,000 each) with regard to avulsed permanent incisors and their emergency management, in and around Davangere. J Indian Soc Pedod Prev Dent. 2006 Sep;24(3):116-21.

25. Krasner P, Person P. Preserving avulsed teeth for replantation. J Am Dent Assoc. 1992 Nov;123(11):80-8.

26. Oliveira TM, Sakai VT, Moretti AS, Silva TC, Santos CF, Machado AM. Knowledge and attitude of mothers with regards to emergency management of dental avulsion. J Dent Child. 2007;74(3):200-202. 